\title{
THE CAUSAL RELATIONSHIP BETWEEN GOVERNMENT REVENUE AND EXPENDITURE IN NAMIBIA
}

\author{
Joel H Eita* \\ University of Namibia, Namibia \\ hinaeita@yahoo.co.uk \\ eitajh@unam.na \\ Daisy Mbazima \\ Bank of Namibia, Namibia \\ Daisy.Mbazima@bon.com.na
}

August 2008

\begin{abstract}
The relationship between government revenue and government expenditure is important, given its relevance for policy especially with respect to the budget deficit. The purpose of this paper is to investigate the relationship between government revenue and government expenditure in Namibia. It investigates the causal relationship between government revenue and government expenditure using the Granger causality test through cointegrated vector autoregression (VAR) methods for the period the period 1977 to 2007. The paper tests whether government revenue causes government expenditure or whether the causality runs from government expenditure to government revenue, and if there is bi-directional causality. The results show that there is unidirectional causality from government revenue to government expenditure. This suggests that unsustainable fiscal imbalances can be mitigated by policies that stimulate government revenue.
\end{abstract}

\section{Keywords:}

Government expenditure, government revenue, causality, cointegration, revenue-spend, spendrevenue, fiscal synchronisation, Namibia 


\section{INTRODUCTION}

A sound fiscal policy is important to promote price stability and sustain growth in output and employment. In many debates concerning macroeconomic policy, fiscal policy is regarded as an instrument that can be used to lessen short-run fluctuations in output and employment. It can also be used to bring the economy to the level of its potential. If policymakers understand the relationship between government expenditure and government revenue, continuous government deficits can be prevented. Hence the relationship between government expenditure and government revenue has attracted significant interest. This is due to the fact that the relationship between government revenue and expenditure has an impact on the budget deficit. The causal relationship between government revenue and expenditure has remained an empirically debatable issue in the field of public finance. The question of which variable takes precedence over the other, has been a central issue to this debate.

On the theoretical front, several hypotheses have resulted from the causal relationship between government revenue and government expenditure (Li, 2001; Fasano and Wang, 2002; Narayan and Narayan, 2006; Gounder, et al., 2007). The first hypothesis is the revenue-spend hypothesis, where raising revenue leads to more expenditure. The causality runs from government revenue to government expenditure. The second hypothesis is spend-revenue, which states that changes in government expenditure cause changes in government revenue. This hypothesis was advocated by Peacock and Wiseman (1961). The third hypothesis is fiscal synchronisation, which states that government revenue decisions are not made in isolation from government expenditure decisions. The decisions are made concurrently. The causality runs from both directions (bidirectional causality).

Narayan and Narayan (2006) gave three reasons why the nature of the relationship between government expenditure and government revenue is important. The first one states that, if the revenue-spend hypothesis holds, budget deficits can be avoided by the implementation of policies that stimulate government revenue. The second reason states that, if the bi-directional causality does not hold, this suggests that government revenue decisions are made independent of government expenditure decisions. This can cause high budget deficits should government expenditure rise faster than government revenue. The third reason is that if the spend-revenue hypothesis holds it suggests that the government spends first and pays for this spending later by raising taxes. This will result in the fear of paying more taxes in the future and encourage the outflow of capital.

The relationship between government expenditure and government revenue has been investigated for a number of countries. Studies such as Von Fursterburg, Green and Jeong (1986), and Anderson, Wallace and Warner (1986) revealed evidence of causality from government expenditure to government revenue for a number of developed countries. This study was supported by Narayan and Narayan (2006) for Peru and provided evidence of the spend-revenue hypothesis. Other studies found evidence of causality running from government revenue to government expenditure (such as Manage \& Marlow, 1986). Narayan and Narayan (2006) also found evidence of causality from revenue to expenditure for Mauritius, \&l Salvador, Haiti, Chile and Venezuela. These studies provided evidence of the revenue-spend hypothesis. A number of studies found evidence of the fiscal synchronisation hypothesis (such as Owoye, 1995; Li, 2001; Fasano \& Wang, 2002; Gounder, Narayan \& Prasad, 2007). They found evidence of bi-directional causality between government expenditure and government revenue. 
In Namibia, the macroeconomic policy framework takes into account the macroeconomic aspects of the economy and forms the basis on which expenditure needs are balanced with the potential for revenue. The macroeconomic framework is viewed as a mechanism that is aimed to ensure that the government structures the budget within the available resources. Priority areas are given preferences in budgeting. Before Namibia's independence in 1990, the country's budgetary system was highly integrated with that of South Africa. Since independence, Namibia's national budgeting has been and still is guided by development priorities set out in National Development Plans and by fiscal targets that the country has set for itself. The Transitional Development Plan came first, and applied to the period 1991/1992 to 1993/1994. It was followed by the First National Development Plan (NDPI) for the period 1995/1996 to $1999 / 2000$, and the Second National Development Plan (NDPII) was for the period 2001/2002 to 2005/2006. The Medium Term Expenditure Framework (MTEF) was introduced in 2001 with the aim of implementing a fully-fledged budgeting system. Reforms and budgetary tools such as the Performance Effectiveness Management Programme (PEMP) were introduced in 1999. The first MTEF, which included the first stage of the PEMP, was published at the beginning of the 2001/2002 financial year (Shilimela \& Naimhwaka, 2005). According to Shilimela and Naimhwaka, these reforms and budgetary tools were introduced in addition to the two types of budgets - namely, operational and development. Shilimela and Naimhwaka further argue that Namibia did not implement the conventional World Bank MTEF in its original form: the country formulated its own MTEF, which is a budget in its own right. Under the MTEF budgetary process, most countries (including Namibia) base their expenditure plans on expected GDP growth and expected government revenue.

Despite the fact that the relationship between government revenue and government expenditure is important to evaluating how to address fiscal imbalances, empirical research on this issue in Namibia is scarce. The objective of this study is to test the causality between government revenue and government expenditure. It tests the validity of the various hypotheses for the period 1977 to 2007. The rest of the paper is organised as follows. Section 2 discusses the causality theory concerning government revenue and government expenditure. Section 3 presents the estimation technique and empirical methodology. Section 4 discusses the data and estimation results, while Section 5 concludes the discussion.

\section{GOVERNMENT REVENUE AND GOVERNMENT EXPENDITURE: A GRANGER CAUSALITY ANALYSIS}

The Granger causality test was developed by Granger (1969). According to Granger a variable (in this case government revenue) is said to cause another variable (government expenditure) if past and present values of government revenue help to predict government expenditure. To test whether government revenue Granger-causes government expenditure, this paper applies the causality test developed by Granger (1969). A simple Granger causality test involving two variables, government revenue and government expenditure, is written as:

$$
\text { GOVEX }_{t}=\sum_{j=1}^{p} \eta_{j} \text { GOVREV }_{t-j}+\sum_{j=1}^{p} \gamma_{j} \text { GOVEX }_{t-j}+v_{t}
$$


GOVREV $_{t}=\sum_{j=1}^{p} \alpha_{j}$ GOVREV $_{t-j}+\sum_{j=1}^{p} \beta_{j}$ GOVEX $_{t-j}+u_{t}$

where GOVREV is government revenue and GOVEX is government expenditure. The null hypotheses to be tested are:

$\mathrm{H}_{1}: \dot{\eta}_{j}=0, j=1 \ldots p$ : this hypothesis means that government revenue does not Granger-cause government expenditure.

$\mathrm{H}_{2}: \beta_{j}=0, j=1 \ldots p$ : this hypothesis means that government expenditure does not Granger-cause government revenue. If none of the hypotheses are rejected, it means that government revenue does not Granger-cause government expenditure and government expenditure also does not Granger-cause government revenue. It indicates, in other words, that the two variables are independent of each other. If the first hypothesis is rejected, it shows that government revenue Granger-causes government expenditure. Rejection of the second hypothesis means that the causality runs from government expenditure to government revenue. If all hypotheses are rejected, there is bi-directional causality between government revenue and government expenditure.

The traditional Granger causality test uses the simple $F$-test statistics. Several studies, such as those by Chow (1987), Marin (1992), Pomponio (1996), McCarville and Nnadozie (1995) and Darat (1996), have used the traditional (F-test) to test for causality. The use of simple traditional Granger causality has been identified by several studies (such as Engle \& Granger, 1987; Toda \& Yamamoto, 1995; Zapata \& Rambaldi, 1997; Tsen, 2006; Ahmad \& Harnhirun, 1996; and Shan \& Tian, 1998) as not sufficient if variables are $I(1)$ and cointegrated. If time series included in the analysis are $I(1)$ and cointegrated, the traditional Granger causality test should not be used, and proper statistical inference can be obtained by analysing the causality relationship on the basis of the error correction model ( $(C M)$. Many economic time-series are $I(1)$, and when they are cointegrated the simple F-test statistic does not have a standard distribution. If the variables are $I(1)$ and cointegrated, Granger causality should be done in the $\varepsilon C M$ and expressed as:

$$
\begin{aligned}
& \Delta \operatorname{GOVREV}_{t-1}=\sum_{j=1}^{p} \alpha_{j} \Delta \operatorname{GOVREV}_{t-j}+\sum_{j=1}^{p} \beta_{j} \Delta G O V E X_{t-j}+\phi_{1} \varepsilon_{1 t-1}+u_{t} \\
& \Delta \text { GOVEX }_{t-1}=\sum_{j=1}^{p} \eta_{j} \Delta \text { GOVREV }_{t-j}+\sum_{j=1}^{p} \gamma_{j} \Delta G O V E X_{t-j}+\phi_{2} \varepsilon_{2 t-1}+v_{t}
\end{aligned}
$$

where $\varepsilon_{1 t-1}$ and $\varepsilon_{2 t-2}$ are the lagged values of the error term from the following cointegration equations:

$G O V R E V_{t}=\delta+\varphi G O V E X_{t}+\varepsilon_{1 t}$

GOVEX $_{t}=a+\psi G O V R E V_{t}+\varepsilon_{2 t}$ 


\section{ESTIMATION TECHNIQUE AND EMPIRICAL METHODOLOGY}

The first step in the empirical estimation is the univariate characteristics, which show whether the variables are stationary or non-stationary. If the variables are non-stationary, their order of integration is tested. This paper uses the Augmented Dickey-Fuller (ADF) and Phillips-Perron statistics to test the stationarity or non-stationarity of the variables and their order of integration. If the variables are $I(1)$, the next step is to test whether they are cointegrated. This is done by using the Johansen (1988; 1995) full information maximum likelihood. This econometric methodology corrects for autocorrelation and endogeneity parametrically using a vector error correction mechanism (VECM) specification. The Johansen procedure is described as follows. Defining a vector $x_{t}$ of $n$ potentially endogenous variables, it is possible to specify the data generating process and model $x_{t}$ as an unrestricted vector autoregression (VAR) involving up to $k$-lags of $x_{t}$ specified as:

$$
x_{t}=\mu+A_{1} x_{t-1}+\ldots \ldots+A_{k} x_{t-k}+\varepsilon_{t} \quad u_{t} \sim \operatorname{IN}\left(0, \sum\right),
$$

where $x_{t}$ is $(n \times l)$ and each of the $A_{i}$ is an $(n \times n)$ matrix of parameters. Sims (1980) advocates this type of VAR modelling as a way of estimating dynamic relationships among jointly endogenous variables without imposing strong a priori restrictions (see also Harris, 1995). This is a system in reduced form and each variable in $x_{t}$ is regressed on the lagged values of itself and all the other variables in the system. Equation (7) can be re-specified into a vector error correction model (VECM) as:

$$
\Delta x_{t}=\mu+\Gamma_{1} \Delta x_{t-1}+\ldots . .+\Gamma_{k-1} \Delta x_{t-k+1}+\Pi x_{t-k}+\varepsilon_{t}
$$

where $\Gamma_{i}=-\left(I-A_{1}-\ldots . .-A_{i}\right),(i=1, \ldots ., k-1)$ and $\Pi=-\left(I-A_{i}-\ldots \ldots .-A_{k}\right), /$ is a unit matrix, and $A_{i}(i=1, \ldots . . p)$ are coefficient vectors, $\rho$ is the number of lags included in the system, $\varepsilon$ is the vector of residuals which represents the unexplained changes in the variables or influence of exogenous shocks. The $\Delta$ represents variables in differenced form, which are $I(0)$ and stationary and $\mu$ is a constant term. Harris (1995:77) states that this way of specifying the system has information on both the short- and long-run adjustment to changes in $x_{t}$ through estimates of

$\Gamma_{i}$ and $\Pi$ respectively. In the analysis of VAR, $\Pi$ is a vector that represents a matrix of long-run coefficients and is of paramount interest. The long-run coefficients are defined as a multiple of two $(n \times r)$ vectors, $\alpha$ and $\beta^{\prime}$, and hence $\Pi=\alpha \beta^{\prime}$, where $\alpha$ is a vector of the loading matrices and denotes the speed of adjustment from disequilibrium, while $\beta^{\prime}$ is a matrix of longrun coefficients so that the term $\beta^{\prime} x_{t-1}$ in Equation (8) represents up to $(n-1)$ cointegration relationships in the cointegration model. It is responsible for making sure that the $x_{t}$ converge to their long-run steady-state values. Evidence of the existence of cointegration is the same as evidence of the rank ( $r$ ) for the $\Pi$ matrix. If it has a full rank, the rank $r=n$ and it is said that there are $n$ cointegrating relationships and that all variables are $I(0)$. If it is assumed that $x_{t}$ is a vector of non-stationary variables $I(1)$, then all terms in Equation (8) which involves $\Delta x_{t-i}$ are $I(0)$, and $\Pi x_{t-k}$ must also be stationary for $\varepsilon_{t} \sim I(0)$ to be white noise. The cointegrating rank is tested with two statistics: the trace and maximum Eigenvalue.

If there is cointegration, it shows evidence of a long-run relationship between the variables and 
the appropriateness of proceeding to test the direction of causality as illustrated in Equations (3) and (4). Cointegrated variables share common stochastic and deterministic trends and tend to move together through time in a stationary manner even though the two variables in this study may be non-stationary. It is important to note that there are three possible cases:

- The rank of $\Pi$ can be zero. This takes place when all elements in the matrix $\Pi$ are zero. This means that the sequences are unit root processes and there is no cointegration. The variables do not share common trends or move together over time. In this case, the appropriate model is a VAR in first differences involving no long-run elements.

- The rank of $\Pi$ could be full (in this study, rank =2). In this case, the system is stationary and the two variables can be modelled by VAR in levels. It represents a convergent system of equations, with all variables being stationary.

- Finally, the rank of $\Pi$ can be a reduced (in this study, rank $=1$ ). In this case, even if all variables are individually $I(1)$, the level-based long-run component would be stationary. In this case, there are $n-1$ cointegrating vectors. The appropriate modelling methodology here is a $V E C M$.

\section{DATA AND ESTIMATION RESULTS}

\subsection{Data}

The study uses annual data and covers the period 1977 to 2007. The data were sourced from Cornwell, Leistner and Esterhuysen (1991) and various issues of the budget statement of the Ministry of Finance of Namibia as well as the Bank of Namibia's Annual Report. Total government revenue and total government expenditure are the two variables used in the estimation.

\subsection{Univariate Characteristics of the Variables}

The first step in the estimation is the univariate characteristics of the variables. It involves testing for the unit root of the variables to be used in the estimation. The results of the unit root tests are presented in TABLE 1.

TABLE 1 shows that the two variables are stationary in levels according to Phillips-Perron statistics. The ADF test statistic indicates that government expenditure is stationary in levels but government revenue is not. This study uses rejection of the null hypothesis of unit root by one test at least to assume a verdict of stationarity. Since the variables are stationary, the next step is to use Johansen (1988; 1995) full information maximum likelihood to test for cointegration. Based on the Akaike information criterion, likelihood ratio, final prediction error, Schwartz information criteria, and Hannan-Quinn information criterion, the lag length was set at 3 . 
TABLE 1: ADF and Phillips-Perron unit root tests

\begin{tabular}{|c|c|c|c|c|}
\hline Variable & $\begin{array}{c}\text { Model } \\
\text { Specification }\end{array}$ & ADF statistic & $\begin{array}{l}\text { Joint test } \\
\text { (F-statistic) }\end{array}$ & Phillips Perron \\
\hline \multirow[t]{2}{*}{ LnGOVREV } & $\begin{array}{l}\text { Intercept and } \\
\text { trend }\end{array}$ & -2.456 & $\Phi_{3}=3.84$ & -2.321 \\
\hline & $\begin{array}{l}\text { Intercept } \\
\text { None }\end{array}$ & $\begin{array}{l}-1.878 \\
5.837\end{array}$ & $\Phi_{1}=23.850$ & $\begin{array}{l}-4.999 \star \star \star \\
5.868\end{array}$ \\
\hline InGOVEX & $\begin{array}{l}\text { Intercept and } \\
\text { trend } \\
\text { Intercept } \\
\text { None }\end{array}$ & $\begin{array}{l}-3.205 \\
-3.084 \star \star\end{array}$ & $\Phi_{3}=9.836$ & $\begin{array}{l}-3.758 \star \star \\
-8.484 \star \star \star \\
5.341\end{array}$ \\
\hline
\end{tabular}

Source: Author

$\star / \star \star / \star \star \star$ significant at $10 \% / 5 \% / 1 \%$ level

Critical values for the $\Phi_{3}$ and $\Phi_{1}$ are from Dickey and Fuller (1981: 1063).

"General to specific" iterative procedure in Enders (2004: 213) is used for ADF test.

Cointegration test results are presented in TABL 2 indicates that there are two cointegrating vectors.

TABLE 2: Cointegration test results

\begin{tabular}{ccccc}
\hline Null hypothesis & $\begin{array}{c}\text { Alternative } \\
\text { hypothesis }\end{array}$ & Test statistic & $\begin{array}{c}0.05 \text { critical } \\
\text { value }\end{array}$ & Probability value $^{b}$ \\
\hline & & Trace statistic & \\
$r=0$ & $r=1$ & $49.215^{a}$ & 20.262 & 0.000 \\
$r=1$ & $r=2$ & $18.683^{a}$ & 9.165 & 0.000 \\
$r=0$ & & Maximum Eigenvalue statistic & \\
$r>0$ & $30.532^{a}$ & 15.892 & 0.000 \\
$r \leq 1$ & $r>1$ & $18.683^{a}$ & 9.165 & 0.000 \\
\hline
\end{tabular}

Source: Author

a Denotes rejection of the null hypothesis at 0.05 level

b Mackinnon-Haug-Michelis (1999) p-values

TABLE 2 shows that there are two economic equilibrium relationships between government revenue and government expenditure. This is a full rank and was expected, since the variables are $I(0)$. Since there are two cointegrating vectors or full rank, the appropriate modelling methodology is to test for causality using VAR in levels. There is no need to do a VECM. The long-run results for the two equations specified in Equations (1) and (2) are (standard errors in parentheses):

$$
\ln \text { GOVREV }=-2.129+1.194 \ln \text { GOVEX }
$$

$$
\text { (0.291) (0.025) }
$$


$\ln$ GOVEX $=-1.783+0.838 \ln$ GOVREV

(10)

(0.224) (0.019)

Equations (9) and (10) indicate a positive relationship between government revenue and government expenditure. The next step is to test the direction of causality between the two variables. The existence of cointegration implies that there must be Granger causality at least in one direction, although it does not indicate the direction of causality among the variables in the estimation. The results are presented in TABLE 3.

TABLE 3: Granger causality test results

\begin{tabular}{ccc}
\hline$H_{0}$ & Wald test/ $\chi^{2}$ & Conclusion \\
\hline $\begin{array}{c}\text { InGOVREV does not Granger } \\
\text { cause InGOVEX }\end{array}$ & $6.240(0.044) \star$ & $\begin{array}{c}\text { Reject the null hypothesis. } \\
\text { There is causality from } \\
\text { In GOVREV to In GOVEX }\end{array}$ \\
$\begin{array}{c}\text { In GOVEX does not Granger } \\
\text { cause InGOVREV }\end{array}$ & $\begin{array}{c}\text { Fail to reject the hypothesis. } \\
\text { There is no causality from } \\
\text { In GOVEX to InGOVREV }\end{array}$ \\
\hline
\end{tabular}

Source: Author

Note: Probabilities are in parentheses

* Rejection of the null hypothesis

TABLE 3 shows that there is Granger causality running from government revenue to government expenditure. This provides evidence of the tax-spend hypothesis in Namibia. Increasing taxes leads to more spending. The budget deficit in Namibia may be eliminated by implementing policies that stimulate government revenue.

\subsection{Impulse responses}

Impulse responses introduced by Sims (1980) shows the response of one variable to shocks in another variable (for example, response of government expenditure to shocks in government revenue). They are important in the analysis of an estimated structural VAR. They show the dynamic response of a variable to a shock in one of the structural equations. They indicate the response of present and future values of each of the variables to a one-unit increase in the present value of one of the shocks of VAR. The impulse responses are presented in FIGURE 1. They are orthogononalised using Cholesky or lower triangular decomposition. The variables are ordered as government expenditure followed by government revenue. 
Response of government expenditure to government expenditure

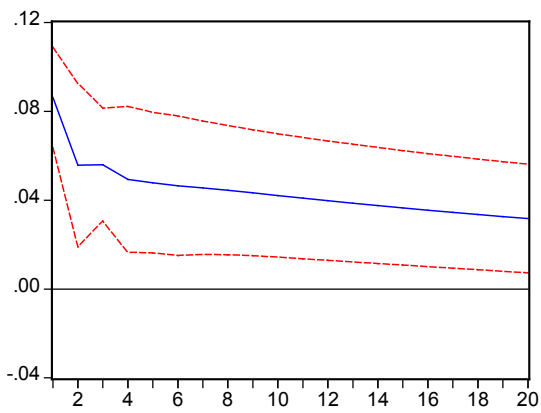

Response of government revenue to government expenditure

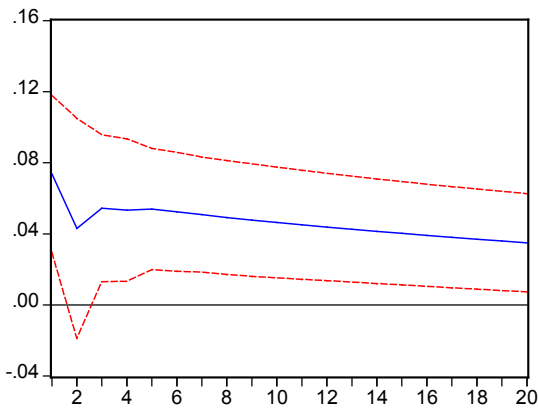

Response of government expenditure to government revenue

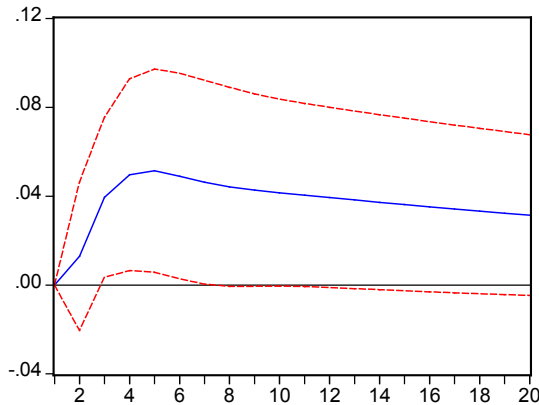

Response of government revenue to government revenue

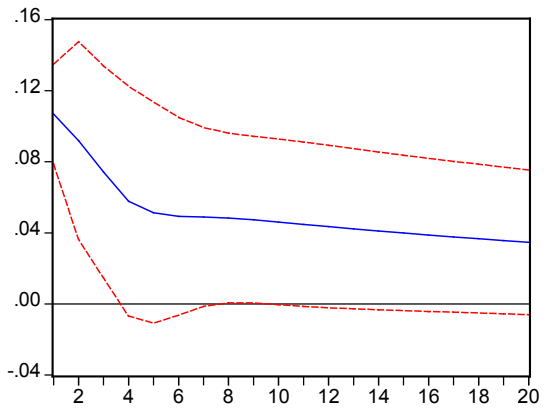

FIGURE 1: Impulse responses

\section{Source: Author}

FIGURE 1 shows that government revenue responds positively to shocks on itself and from government expenditure. Government expenditure also responds positively to shocks on itself and from government expenditure. Although the figure shows a declining trend, the solid line indicates a positive response, as it is in the positive side of the graph.

\section{CONCLUSION}

This paper investigated the relationship between government expenditure and government revenue in Namibia for the period 1977 to 2007. The investigation tested which of the three hypotheses (revenue-spend, spend-revenue and bi-directional) holds for Namibia, using the VAR econometric methodology. The ADF and Phillips-Perron statistics were used to test for unit root. Variables are $I(0)$ and, hence, VAR was employed in levels. The results reveal that there is unidirectional causality from revenue to expenditure, and indicate that there is evidence of the revenue-spend hypothesis for Namibia. The MTEF of Namibia also lends support to the revenue-spend hypothesis. This suggests that unsustainable fiscal deficits can be mitigated by policies that stimulate government revenue. Increase in government revenue gives the government more fiscal space necessary to accommodate expenditure without necessarily jeopardising fiscal sustainability. Evidence of the revenue-spend hypothesis implies that 
government raises revenue first and then spends. This means that economic agents may not have expectations of higher taxes in the future. Potential investors in Namibia may interpret this type of government behaviour in a positive way. In this regard, this paper concludes that in Namibia, where government revenue causes government expenditure, private investment may be encouraged.

\section{REFERENCES}

Ahmad, J. \& Harnhirun, S. (1996). Cointegration and Causality Between Exports and Economic Growth: Evidence from the ASEAN Countries, The Canadian Journal of Economics, 29 (Special issue, part 2), pp. S413-5416.

Anderson, W., Wallace, M. S. \& Warner, J. T. (1986). Government Spending and Taxation: What Causes What?, Southern Economic Journal, 52(3), pp. 630-639.

Chow, P. C. Y. (1987). Causality between Export Growth and Industrial Development: Empirical Evidence from the NICs, Journal of Development Economics, 26(1), pp. 55-63.

Cornwell, R., Leistner, E. \& Esterhuysen, E. (1991). Namibia 1990: An African Institute Country Survey. Pretoria: Africa Institute of South Africa.

Darat, A. F. (1996). Trade and Development: The Asian Experience, Cato Journal, 6(2), pp. 695-699.

Dickey, D. A. \& Fuller, W. A. (1981). Likelihood Ratio Statistics for Autoregressive Time Series with a Unit Root, Econometrica, 49(4), pp. 1057-1072.

Enders, W. (2004). Applied Econometric Time Series. USA: John Wiley and Sons.

Engle, R. F. \& Granger, C. W. J. (1987). Co-Integration and Error Correction: Representation, Estimation and Testing, Econometrica, 55(2), pp. 251-276.

Engle, R. F. \& Yoo, B. S. (1987). Forecasting and Testing in Co-integrated Systems. Journal of Econometrics, 35(1), pp. 143-159.

Fasano, U. \& Wang, Q. (2002). Testing the Relationship between Government Spending and Revenue: Evidence from GCC Countries, IMF Working Paper, WP/02/201. Washington: International Monetary Fund.

Gounder, N., Narayan, P. K. \& Prasad, A. (2007). An Empirical Investigation of the Relationship between Government Revenue and Government Expenditure: The Case of Fiji Islands, International Journal of Social Economics, 34(3), pp. 147-158.

Granger, C. W. J. (1969). Investigating the Causal Relations by Econometric Models and Cross-Spectral Methods, Econometrica, 37(3), pp. 424-238.

Granger, C. W. J. (1988). Some Recent Developments in a Concept of Causality, Journal of Econometrics, 39(1-2), pp. 199-211.

Harris, R. I. D. (1995). Using Cointegration Analysis in Econometric Modelling. London: Prentice Hall/Harvester Wheatsheaf.

Johansen, S. (1988). Statistical Analysis of Cointegrating Vectors, Journal of Economic Dynamic and Control, 12(2-3), pp. 231-254.

Johansen, S. (1995). Likelihood Based Inferences in Cointegrated Vector Autoregressive Models. Oxford: Oxford University Press. 
MacKinnon, J. G., Haug, A. A. \& Michelis, L. (1999). Numerical Distribution Functions of Likelihood Ratio Test for Cointegration, Journal of Applied Econometrics, 14(5), pp. 563-577.

Marin, D. (1992). Is the Export-Led Growth Hypothesis Valid for Industrialised Countries? Review of Economics and Statistics, 74(4), pp. 678-688.

McCarville, M. \& Nnadozie, ع. (1995). Causality Test of Export-Led Growth: The Case of Mexico, Atlantic Economic Journal, 23(2), pp. 140-145.

Li, X. (2001). Government Revenue, Government Expenditure, and Temporal Causality from China, Applied Economic Letters, 33(4), pp. 485-497.

Manage, N. \& Marlow, M. (1986). The Causal Relationship between Federal Expenditure and Receipts, Southern Economic Journal, 52(1), pp. 617-629.

Narayan, P. K. \& Narayan, S. (2006). Government Revenue and Government Expenditure Nexus: Evidence from Developing Countries, Applied Economic Letters, 38(3), pp. 285-291.

Owoye, 0. (1995). The Causal Relationship between Taxes and Expenditure in the G-7 Countries: Cointegration and Error Correction Models, Applied Economic Letters, 2(1), pp. 19-22.

Peacock, A. T. \& Wiseman, J. (1961). The Growth of Public Expenditure in the United Kingdom, National Bureau of Economic Research. Princeton: Princeton University Press.

Pomponio, X. Z. (1996). A Causality Analysis of Growth and Export Performance, Atlantic Economic Journal, 24(2), pp. 168-176.

Von Furstenberg, V. G. M., Green, R. J. \& Jeong, R. J. (1986). Tax and Spend or Spend and Tax, Review of Economics and Statistics, 68(2), pp. 179-188.

Shan, J. and Tian, G. G. (1998). Causality between Exports and Economic Growth: The Empirical Evidence from Shanghai, Australian Economic Papers, 37 (2), pp. 195-202.

Shilimela, R. \& Naimhwaka, દ. (2005). Budgetary Process and Economic Governance in Namibia. NEPRU Working Paper No. 105. Windhoek: NEPRU.

Sims, C. (1980). Macroeconomics and Reality, Econometrica, 48(1), pp. 1-48.

Toda, H. Y. \& Yamamoto, T. (1995). Statistical Inference in Vector Autoregressions with Possibly Integrated Processes, Journal of Econometrics, 66(1-2), pp. 225-250.

Tsen, W. H. (2006). Granger Causality Tests Among Openness to International Trade, Human Capital Accumulation and Economic Growth in China: 1952 - 1999, International Economic Journal, 20(3), pp. 285-302.

Zapata, H. 0. \& Rambaldi, A. N. (1997). Monte Carlo Evidence on Cointegration and Causation. Oxford Bulletin of Economics and Statistics, 59(2), pp. 285-298. 
Eita \& Mbazima 